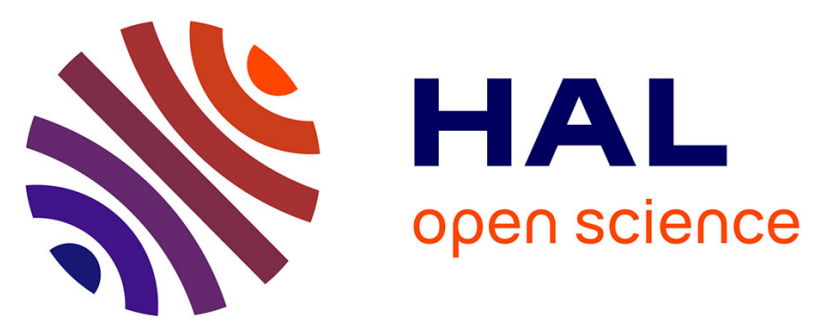

\title{
Effect of a long chain n-3 PUFA-enriched diet on production and reproduction variables in Holstein dairy cows
}

Sébastien Elis, Sandrine Freret, Alice Desmarchais, Virginie Maillard, Juliette Cognie, Eric Briant, Jean-Luc Touze, Mickaël Dupont, Philippe Faverdin, Véronique Chajès, et al.

\section{To cite this version:}

Sébastien Elis, Sandrine Freret, Alice Desmarchais, Virginie Maillard, Juliette Cognie, et al.. Effect of a long chain n-3 PUFA-enriched diet on production and reproduction variables in Holstein dairy cows. Animal Reproduction Science, 2016, 164, pp.121-132. 10.1016/j.anireprosci.2015.11.020 . hal01512139

\section{HAL Id: hal-01512139 \\ https://hal.science/hal-01512139}

Submitted on 21 Apr 2017

HAL is a multi-disciplinary open access archive for the deposit and dissemination of scientific research documents, whether they are published or not. The documents may come from teaching and research institutions in France or abroad, or from public or private research centers.
L'archive ouverte pluridisciplinaire HAL, est destinée au dépôt et à la diffusion de documents scientifiques de niveau recherche, publiés ou non, émanant des établissements d'enseignement et de recherche français ou étrangers, des laboratoires publics ou privés. 


\section{Accepted Manuscript}

Title: Effect of a long chain n-3 PUFA-enriched diet on production and reproduction variables in Holstein dairy cows

Author: Sebastien Elis Sandrine Freret Alice Desmarchais Virginie Maillard Juliette Cognié Eric Briant Jean-Luc Touzé Mickael Dupont Philippe Faverdin Véronique Chajès Svetlana

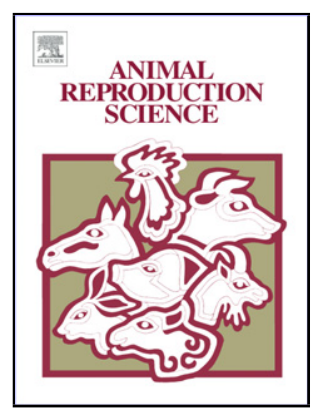
Uzbekova Philippe Monget Joëlle Dupont

PII:

DOI:

Reference:

S0378-4320(15)30063-4 http://dx.doi.org/doi:10.1016/j.anireprosci.2015.11.020

To appear in: ANIREP 5317

Received date: Animal Reproduction Science

Revised date:

$15-7-2015$

Accepted date: $18-11-2015$

Please cite this article as: Elis, S., Freret, S., Desmarchais, A., Maillard, V., Cognié, J., Briant, E., Touzé, J.-L., Dupont, M., Faverdin, P., Chajgravees, V., Uzbekova, S., Monget, P., Dupont, J.,Effect of a long chain n-3 PUFA-enriched diet on production and reproduction variables in Holstein dairy cows, Animal Reproduction Science (2015), http://dx.doi.org/10.1016/j.anireprosci.2015.11.020

This is a PDF file of an unedited manuscript that has been accepted for publication. As a service to our customers we are providing this early version of the manuscript. The manuscript will undergo copyediting, typesetting, and review of the resulting proof before it is published in its final form. Please note that during the production process errors may be discovered which could affect the content, and all legal disclaimers that apply to the journal pertain. 
Effect of a long chain n-3 PUFA-enriched diet on production and reproduction variables

in Holstein dairy cows

Sebastien Elis $^{\text {abcd\# }}$, Sandrine Freret ${ }^{\text {abcd }}$, Alice Desmarchais ${ }^{\text {abcd }}$, Virginie Maillard ${ }^{\text {abcd }}$,

Juliette Cognié $^{\text {abcd }}$, Eric Briant ${ }^{\mathrm{e}}$, Jean-Luc Touzé ${ }^{\text {abcd }}$, Mickael Dupont ${ }^{\mathrm{e}}$, Philippe

Faverdin $^{\text {fg }}$, Véronique Chajès ${ }^{\mathrm{h}}$, Svetlana Uzbekova ${ }^{\text {abcd }}$, Philippe Monget ${ }^{\text {abcd }}$ and Joëlle

Dupont $^{\text {abcd }}$

${ }^{\mathrm{a}}$ INRA, UMR85 Physiologie de la Reproduction et des Comportements, F-37380 Nouzilly, France

${ }^{\mathrm{b}}$ CNRS, UMR 7247 Physiologie de la Reproduction et des Comportements, F-37380

Nouzilly, France

${ }^{\mathrm{c}}$ Université François Rabelais de Tours, UMR Physiologie de la Reproduction et des Comportements, F-37380 Nouzilly, France

${ }^{\mathrm{d}}$ IFCE, UMR Physiologie de la Reproduction et des Comportements, F-37380 Nouzilly, France

${ }^{\mathrm{e}}$ INRA, UE 1297 Physiologie Animale de l'Orfrasière, F-37380 Nouzilly, France

${ }^{\mathrm{f}}$ INRA, UMR 1348 Physiologie Environnement et Génétique pour l'Animal et le Système d'Elevage, F-35590 Saint-Gilles, France

${ }^{\mathrm{g}}$ Agrocampus Ouest, UMR 1348 Physiologie Environnement et Génétique pour l'Animal et le Système d'Elevage, F-35000 Rennes, France

h'Institut Gustave Roussy, F-94805, Villejuif, France

${ }^{\#}$ Corresponding author: Postal address: INRA Centre Val de Loire, Physiologie de la

Reproduction et des Comportements, 37380 Nouzilly, France ; Email address: SE:

$\underline{\text { sebastien.elis@ tours.inra.fr }}$ 


\section{ABSTRACT}

2 The objective of this study was to determine the effect of a rumen-protected fish oil

3 supplement on the production and reproduction variables in postpartum dairy cows.

4 Holstein cows $(n=46)$ were given a basal total mixed diet plus one PUFA

5 supplement: n-3 (n-3; protected fish oil; $1 \%$ dry matter intake (DMI); $n=23$ ) or

6 control ( $\mathrm{n}-6$; toasted soybeans; $1.8 \% \mathrm{DMI} ; n=23)$, in a switchback design over two

7 consecutive lactations. Supplements were added to the diet between calving and 2

8 months after calving to assess the effect on growth and maturation of ovarian follicles

9 from which ovulation occurred around the day of insemination. Body weight (BW),

10 milk yield (MY) and composition, dry matter intake (DMI), energy balance (EB),

11 subcutaneous fat thickness, plasma fatty acid composition, plasma nonesterified fatty

12 acids (NEFA), glucose and urea concentrations, follicular activity, embryo mortalities

13 and fertility (conception rate after first AI, AI1) were assessed. BW, MY, DMI,

14 plasma NEFA, glucose and urea were unaffected by the diet. There was a trend of an

15 increased number of large follicles (diameter $\geq 10 \mathrm{~mm}$ ) with the $\mathrm{n}-3$ dietary

16 supplementation $(P=0.06)$ and a decrease in infertility or early embryo mortality rate

1721 days after AI, $13.5 \%$ in the $n-3$ compared with $38.8 \%$ in the $n-6$ group $(P=0.09)$,

18 with no effect on the conception rate at $35 \mathrm{~d}$ or $90 \mathrm{~d}$ after AI1. These data suggest that

19 the effect seen on ovarian variables is not associated with an effect on production and

20 metabolic variables and is specific to n-3 PUFA supplementation. Further studies are

21 necessary to determine whether DHA or EPA enhances fertility in lactating dairy

22 cattle.

24 Keywords: Dairy cows, Fertility, n-3 PUFA, Nutrition, Production 


\section{Introduction}

Reproductive performance in cows is influenced by nutritional and metabolic status, as previously reviewed (Butler, 2000; Roche, 2006; Leroy et al., 2008). Therefore, dietary fat has been used to enhance reproductive status. It is well accepted that dietary fat directly affects dairy cow fertility rather than by modifying energy status of cows (Staples et al., 1998; Mattos et al., 2000). Fatty acids (FA) and polyunsaturated FA (PUFA) were found to be important for various reproductive processes, especially as steroid hormone and prostaglandin precursors via cholesterol and arachidonic acid, respectively (Urlep and Rozman, 2013; Tessaro et al., 2015). Among the PUFA, previous research has focused on the effect of omega-6 (n-6) and especially omega-3 (n-3) FA.

The n-3 PUFA belong to a family of biologically active FA. The n-3 PUFA are essential FA as mammals cannot synthesize n-3 PUFA have to be introduced into the body via the diet. The shortest member of this family, alpha-linolenic acid (ALA, C18:3), has an 18 carbon chain and can be converted by a series of desaturation and elongation reactions into more biologically active compounds (Simopoulos, 2002; Plourde and Cunnane, 2007) of the n-3 family: eicosapentaenoic acid (EPA, C20:5) and docosahexaenoic acid (DHA, C22:6) (Calder, 2012). The ALA can be found in several vegetarian sources, such as grass silage, linseed or dehydrated alfalfa. The conversion rate of ALA into EPA and DHA is low in mammals (Burdge and Calder, 2005). Therefore, to increase concentrations of EPA and DHA in plasma of dairy cows, these two n-3 PUFA have to be directly introduced into the body via the diet. The EPA and DHA are found in fish oil, as well as in microalgae oil (Abughazaleh et al., 2009). 
The n-3 PUFA have a wide range of physiological roles, via receptors, sensors or cell membrane fatty acid composition (membrane order, lipid rafts etc...; reviewed in (Calder, 2012)). Among the physiological roles of n-3 PUFA, there is an effect on reproductive variables. There is a greater pregnancy rate because of a decrease in embryo mortality with feeding of a flaxseed diet (Petit and Twagiramungu, 2006). The feeding of an n-3 diet (enriched in ALA) led to an increase in the size of the preovulatory follicles (Ambrose et al., 2006) and in number of small follicles (Zachut et al., 2010). The feeding of diets supplemented with n-3 PUFA (enriched in ALA) also had a tendency towards increasing conception rates (Ambrose et al., 2006; Dirandeh et al., 2013). One mechanism that could enhance fertility is that the $n-3$ diet decreases the concentration of prostaglandin $\mathrm{F} 2$ alpha $(\mathrm{PGF} 2 \alpha)$ in the uterus, thus potentially facilitating embryo implantation and reducing embryo mortality (Mattos et al., 2004). However, some inconsistencies exist, likely due to dose and/or PUFA form differences, both fish oil (EPA, DHA) and flaxseed (ALA) diets were reported to decrease corpora lutea (CL) size, and consequently plasma progesterone concentrations, leading to a more unfavorable uterine environment for sustaining pregnancies and reduced fertility (Hutchinson et al., 2012).

The objective of the present study was, thus, to assess the effect of a moderate amount of rumen-protected n-3 PUFA on production [body weight (BW), milk yield (MY), dry matter intake (DMI), energy balance (EB), milk fat content (MFC), milk protein content (MPC), subcutaneous fat thickness and metabolic variables, nonesterified fatty acids (NEFA), glucose, urea, as well as on ovarian variables, growing follicle numbers, conception rate after first AI (AI1)] of 25 Holstein dairy cows in which assessments occurred over two lactations. Long chain n-3 PUFA (DHA and EPA) were chosen because these molecules are the most efficient n-3 
75 PUFA candidates (Simopoulos, 2002; Deckelbaum and Torrejon, 2012). Rumen76 protected fish oil was used to provide DHA and EPA. To ensure a specific effect of 77 long chain n-3 PUFA, an n-6 PUFA diet was chosen as the control. It was 78 hypothesized that the n-3 diet could enhance not only the uterine environment (Mattos 79 et al., 2004) but also oocyte quality, independent of a secondary effect on production 80 or metabolism modifications. Therefore, the diets were fed from calving to 2 months 81 postpartum (2MPP), thus potentially affecting ovarian folliculogenesis and thus the 82 qualitative properties of oocytes released at the ovulation associated with AI1.

83 


\section{Materials and methods}

\subsection{Animals and experimental design}

All experimental protocols were approved by the local ethics committee "Comité d'Ethique en Expérimentation Animale Val de Loire (CEEA VdL)" (protocol registered under ref. 2012-01-1), in accordance with European Directive 2010/63/EU on the protection of animals used for scientific purposes. Holstein cows $(n=25)$ were managed in loose housing and monitored over 2 consecutive years (21/25 cows were monitored during the second year) in the same dairy herd in a switchback design. Each cow received either n-3 or n-6 diets the first year, and the other diet the following year. For the first year of the experiment, cows were either in their first $(n=7)$ or second $(n=18)$ lactation. The number of cows used in the experimental design is presented in Table 1. At the end of the experiment, a total of 23 cows received the n-3 diet and a total of 23 cows received the n- 6 diet. Cows originated from a population previously selected for one female fertility QTL located on bovine chromosome 3, and carried either a favorable (Fertil+) or unfavorable (Fertil-) haplotype (Coyral-Castel et al., 2011; Coyral-Castel et al., 2012a). As this QTL affected reproductive variables during the first lactation, cows with each haplotype were equally distributed in the two dietary groups (n-3 diet group: 14 Fertil+ and 9 Fertil- cows; n-6 diet group: 15 Fertil+ and 8 Fertil- cows) and the haplotype effect was taken into account.

\subsection{Experimental diets and dry matter intake}

The composition of the two experimental diets was balanced for energy and protein contents as indicated in Table 2; the two diets were total mixed rations (TMR), with feed values being calculated using the INRA French feeding system 
109 (INRA, 2007). The long chain n-3 fatty acid supplement (n-3 diet) was a rumen-

110 protected encapsulated fish oil OMG750® (Kemin, Nantes, France) and the n-6 fatty

111 acid supplement (n-6 diet) was toasted soybeans Danex® (Agralys, Blois, France).

112 The supplements were manually mixed into the diet (at $1 \%$ DM for $n-3$ diet 113 and at $1.8 \%$ DM for $\mathrm{n}-6$ diet) and the TMR were distributed twice daily in individual 114 weighing troughs (Insentec B.V., Marknesse, The Netherlands) as described in 115 Coyral-Castel et al., 2012b. Cows were fed ad libitum and DMI was determined from 116 the composition of the diets, the feed intake and the dry matter content of each 117 ingredient included in the diets. The DMI was analyzed daily during the distribution 118 of the n-3 or n-6 diets, from calving to 2 months postpartum (2MPP).

119 From 2MPP to the non-lactating period, the diet was the same for both groups 120 and contained (\% DM): $68 \%$ corn silage, $8 \%$ dehydrated alfalfa, $11 \%$ Sandifort ${ }^{\circledR}$ 121 (wheat), 12\% Sandilait ${ }^{\circledR}$ (soybean and rapeseed meal), 0.4\% vitamins and minerals $5 / 23$ and $0.5 \%$ calcium bicarbonate.

\subsection{Body weight, milk yield and composition, energy balance}

Body weight (BW) and milk yield (MY) were monitored daily during the milking period, from calving to 5 months postpartum (5MPP). All cows were milked twice daily. In the milking parlor, the MY $(\mathrm{kg} / \mathrm{d})$ of each cow was automatically

128 recorded (software Manufeed 500 pro, vc5 version 2.011.14). During the first year of 129 the experiment, individual milk samples were collected at two consecutive milkings 130 once a week to determine milk protein content (MPC, g/L) and milk fat content 131 (MFC, g/L) with Mid-Infrared technics (FOSS, Nanterre, France). After each milking 132 period, cows were automatically weighed (software RIC version RW1.7). Only the 133 BW recorded in the morning was used for statistical analysis. 

months postpartum (2MPP) and corresponds to the difference between net energy

136 intake and net energy needs for body maintenance and lactation (cows were 137 inseminated only after 2MPP), according to the INRA method (INRA, 2007). The 138 nutritional values of the different ingredients composing the diets were available from 139 chemical analysis.

140

141 2.4. Progesterone and metabolic assays, fatty acid composition of plasma and milk

142 Plasma progesterone was determined using an ELISA assay (Canepa et al., 1432008 ) from $10 \mu \mathrm{L}$ of undiluted plasma in samples collected three times a week from 14415 days postpartum to the first artificial insemination (AI1) and then daily from the 145 day of AI1 to 35 days after AI1.

146 For metabolic assays, plasma samples were collected once a week from caudal 147 venipuncture before diet distribution, from 1-month antepartum (1MAP) to 5 months 148 postpartum (5MPP). Plasma samples were stored at $-20{ }^{\circ} \mathrm{C}$ until the assays were 149 conducted. Plasma NEFA, urea and glucose were determined using enzymatic 150 colorimetry on a multi-parameter analyzer (KONE Instruments Corporation, Espoo, 151 Finland). Plasma and milk fatty acid compositions were determined using gas 153 chromatography, as previously described (Chajes et al., 2008; Bernard et al., 2009).

154 Plasma fatty acid composition was determined during the 2 years of the experiment 155 for 13 cows in the n-3 diet group and 16 cows in the n- 6 diet group, in 1 month 156 antepartum (1MAP), 1 week postpartum (1WPP), 2 month postpartum (2MPP) and 5 157 month postpartum (5MPP) samples. Milk fatty acid composition was determined in 
158 2MPP samples only during the first year of the experiment in samples from six cows

159 in the n-3 diet group and six cows in the n-6 diet group.

160

161

\subsection{Subcutaneous adipose tissue thickness}

162

Adipose tissue mobilization was assessed through subcutaneous fat thickness

163

164

165

166

167

168

169

170

171

172

173

174

175

176

177

178

179

180

181

182

\subsection{Ovarian variables and fertility}

During the feeding period of n-3 or n- 6 diets, the ovarian follicular dynamics

of cows $(n=46)$ was monitored three times a week, from $15 \pm 2$ days postpartum to $82 \pm 23$ days postpartum, with a trans-rectal ultrasonographic examination using a linear probe (LV 513 6.0/8.0-MHz transducer; Mylab30vet; Esaote) LA332 3.5/10.0$\mathrm{MHz}$, allowing for the detection and measurement of antral follicles, as previously described (Coyral-Castel et al., 2011). Follicles with a diameter of 3 to $5 \mathrm{~mm}$ were counted and for all follicles greater than $5 \mathrm{~mm}$, the diameter was recorded. Based on these repeated ultrasonographic examinations, the growth of each follicle was assessed in the two ovaries as previously described (Sirois and Fortune, 1988; CoyralCastel et al., 2011). Ovarian follicles were classified according to diameter (Lucy et al., 1992): small follicles ( $3 \leq \mathrm{SF}<5 \mathrm{~mm})$, medium follicles $(5 \leq \mathrm{MF}<10 \mathrm{~mm})$ and large follicles $(\mathrm{LF} \geq 10 \mathrm{~mm}$ ). To be more accurate in the description of LF, this follicle size category was divided into $\mathrm{LFa}(10 \leq \mathrm{LFa}<15 \mathrm{~mm})$ and $\mathrm{LFb}(15 \leq \mathrm{LFb}<$ $25 \mathrm{~mm}$ ). The mean total number of follicles in each category (SF, MF and LF) was 
183 calculated per week postpartum for each cow. Follicular cysts, defined as follicular

184 structures with a diameter larger than $25 \mathrm{~mm}$ and from which ovulation did not occur

185 or that did not regress spontaneously, were excluded from the analysis. Numbers of

186 CL were also recorded.

187 Ovulations were determined from to two consecutive ultrasonographic 188 examinations (separated by 2 or 3 days): when a pre-ovulatory follicle was detected at 189 one examination, and had disappeared at the subsequent examination. Ovulations

190 were always confirmed by the visualization of CL during examinations that occurred

191 subsequent to the time when ovulation was detected. The first postpartum ovulation

192 was recorded for each cow. For some cows, CL were visualized on the first

193 postpartum examination. Estrous cycle durations were calculated between two

194 consecutive ovulations, and the number of waves of ovarian follicular development

195 was recorded.

Cows were artificially inseminated after 60 days postpartum with semen of the

same bull, $12 \mathrm{~h}$ after visual detection of estrus (observation of standing estrus and/or repetition of secondary signs of estrus). One cow was not inseminated during the first year of the study because she never expressed any signs of estrus.

Pregnancy status was determined $21 \mathrm{~d}$ after AI1 by plasma progesterone assay

201 (Canepa et al., 2008), and subsequently 35 and $90 \mathrm{~d}$ after AI1 using ultrasonographic

202 examination. The percentage of non-fertilization and/or early embryo mortality (NF-

203 EEM) was ascertained by the number of non-pregnant cows at $21 \mathrm{~d}$ after AI1 (cows 204 with plasma progesterone $<1 \mathrm{ng} / \mathrm{mL}$ ) divided by the total number of inseminated 205 cows. The percentage of cows with a prolonged luteal phase or late embryo mortality 206 (PLP-LEM) was ascertained by the number of non-pregnant cows at $35 \mathrm{~d}$ divided by 207 the number of cows with plasma progesterone $\geq 1 \mathrm{ng} / \mathrm{mL}$ at $21 \mathrm{~d}$ after AI. First 
service conception rate (CRAI1) at 35 and $90 \mathrm{~d}$ after AI1 was ascertained by the number of pregnant cows (ultrasonographic examination) divided by the total number of inseminated cows. The percentage of cows with late embryo mortality or fetal

212 divided by the number of pregnant cows at $35 \mathrm{~d}$. Interval to first insemination (IFI) 213 was the interval from calving to AI1.

\subsection{Statistical analyses}

All statistical analyses were performed with SAS® software (SAS Institute

217 Inc., 2011). Mean milk fatty acid concentrations at 2MPP during the first year of the experiment were compared between the groups of cows fed the n-3 and n-6 diets using a Student's t-test (TTEST procedure). All other variables (except NF-EEM, PLP-LEM, LEM-FM and CRAI1) were analyzed using a linear mixed model (MIXED procedure) for repeated measurements. For plasma fatty acid composition, the model included the effects of year of experiment, diet, stage ante/postpartum and all interactions, with stage as a repeated effect within cow (year) with a CS covariance structure (repeated statement of the MIXED procedure). Haplotype was not included in the model.

For subcutaneous adipose tissue thickness, the model included the effects of year of experiment, diet, stage ante/postpartum, haplotype and all interactions, with

228 the subcutaneous adipose tissue thickness value at 1MAP as a covariable, and with 229 stage as a repeated effect within cow (year) with a CS covariance structure.

230 Concerning the parameters BW, MY, DMI and EB, the model included the 231 effects of year of experiment, diet, week postpartum (WPP), haplotype and all 232 interactions, with week postpartum as a repeated effect within cow (year) with a 
AR(1) covariance structure and with the value of BW at WPP1 as a covariable for

234 MY and DMI.

For milk composition (MFC and MPC) during the first year of the experiment, the model included the effects of diet, WPP, haplotype and all interactions, with WPP as a repeated effect within cow (year) with a CS covariance structure and with the value of BW at WPP1 as a covariable.

For plasma metabolic variables (NEFA, glucose, urea), the model included the effects of year of experiment, diet, week ante/postpartum (WPP), haplotype and all interactions, with WPP as a repeated effect within cow (year) with a AR(1) covariance structure and with the value of the WPP-4 (week 4 antepartum) as a covariable.

For the follicular growth variables and number of $\mathrm{CL}$, the model included the effects of year of experiment, diet, WPP, haplotype and all interactions, with WPP as a repeated effect within cow (year) with a AR(1) covariance structure.

For the day of first postpartum ovulation, estrous cycle duration, number of follicular waves and IFI, the model included the effects of year of experiment, diet, haplotype and diet $\mathrm{x}$ haplotype interaction.

The NF-EEM, PLP-LEM, LEM-FM and CRAI1 were analyzed using a logistic regression (GLIMMIX procedure) and the model included the effects of year of experiment, diet, haplotype and diet x haplotype interaction.

Least square means (lsmeans) estimated by the models were subsequently compared between diets using a Bonferroni adjustment for multiple comparisons. Results are presented in tables and figures as lsmeans \pm SEM, unless otherwise stated. A difference with $P \leq 0.05$ is considered significant and with $0.05<P \leq 0.10$ is considered a tendency. NS means non-significant for $P$-values $>0.10$. 
258

$-13-$

Comment citer ce document:

Elis, S. Fréret, S., Desmarchais, A. Maillard, V., Cognié, J. Briant, E., Touze, J-L.

Dupont, M., Faverdin, P., Chajès, V., Uzbekova, S., Monget, P., Dupont, J. (2016). Effect of a long

Page 13 of 37 chain n-3 PUFA-enriched diet on production and reproduction variables in Holstein dairy cows. 


\section{Results and discussion}

It was hypothesized that the n-3 diet would enhance oocyte quality independently from a secondary effect on production or metabolism modifications.

\subsection{Efficiency of the diet: Plasma and milk fatty acid composition enrichment in n-3} PUFA

To assess the efficiency of the n-3 diet, plasma fatty acid composition (Table 3) was measured at different stages: before the n-3 diet period (1MAP), during the n-3 diet period (1WPP and 2MPP) and after the n-3 diet period (5MPP). As expected, only a few differences were reported between both diets. The EPA (C20:5 n-3) and DHA (C22:6 n-3), both supplied by the n-3 diet, were increased in the $n-3$ group at both 1WPP $(P=0.0001$ and $P=0.01$, respectively) and 2MPP $(P<0.0001)$. Consequently, the n-6 PUFA-n-3 PUFA ratio was less with the n-3 group, at both 1WPP and 2MPP, by $29 \%(P<0.0001)$ and $41 \%(P<0.0001)$, respectively, compared to the n-6 group. Milk fatty acid composition was also assessed at 2MPP during the first year (Table 4). Feeding of both EPA and DHA increased milk composition of these FA more than three-fold $(P<0.05)$.

Long chain n-3 EPA and DHA are thought to not be biohydrogenated to a significant extent by rumen microorganisms, except for the C18 n-3 fatty acids (Ashes et al., 1992) but there are inconsistencies in thought in this regard (CastanedaGutierrez et al., 2007). Thus, in the present study protected fish oil was chosen so as to maximize the proportion of EPA and DHA in plasma. The rumen-protected form (microencapsulated oil) is sufficient to enable a significant increase in plasma after the first WPP diet, even with the moderate amounts in the diet. The FO diet has been described to increase EPA and DHA in both plasma (Ashes et al., 1992) and milk 
284 (Cant et al., 1997). In addition, FO was reported to decrease the n-6:n-3 ratio in all

285

286 tissues and milk fat except for subcutaneous and internal adipose tissue (Bilby et al., 2006b), as well as ovarian compartments (Zachut et al., 2010). Therefore, the n-3 diet of the present study might decrease the $n-6: n-3$ ratio in the reproductive tissues, consequently exerting the physiological effects previously described.

\subsection{Production variables: $B W, M Y, D M I$, fat thickness, EB, MFC and MPC}

The BW and MY were recorded daily during 22 weeks after calving. The average BW was, throughout the period studied, $593.5 \pm 9.2 \mathrm{~kg}$ in the $\mathrm{n}-3$ group compared to $586.9 \pm 9.1 \mathrm{~kg}$ in the $\mathrm{n}-6$ group, with no difference between groups (diet effect $P=0.61$; Figure 1A). The average MY was, throughout the period studied, 33.0 $\pm 0.8 \mathrm{~kg} / \mathrm{d}$ in the $\mathrm{n}-3$ group, compared with $34.4 \pm 0.8 \mathrm{~kg} / \mathrm{d}$ in the $\mathrm{n}-6$ group, with no difference between groups (diet effect $P=0.25$; Figure 1B).

The MFC and MPC were also assessed once a week during the first year of the experiment for 22 weeks after calving. The average MFC was, throughout the period studied, $46.3 \pm 1.8$ in the $\mathrm{n}-3$ group compared with $48.5 \pm 1.8 \mathrm{~g} / \mathrm{L}$ in the $\mathrm{n}-6$ group, with no difference between groups (diet effect $P=0.41$; Figure $1 \mathrm{C}$ ). The MPC differed between groups $(P=0.05)$ during the first week of lactation $(36.5 \pm 0.6$ compared with $34.3 \pm 0.9 \mathrm{~g} / \mathrm{L}$ milk in the n-3 and n-6 groups, respectively; Figure 1D). Except for the difference reported at WPP1, MPC was not different between the n-3 and n-6 groups (29.7 \pm 0.3 and $29.4 \pm 0.3 \mathrm{~g} / \mathrm{L}$, respectively, diet effect $P=0.53)$.

The DMI and energy balance (EB) were measured during the first 8 weeks postpartum (period of n-3 and n-6 diet distribution). The DMI was not different between groups (diet effect $P=0.46$ ), $13.5 \pm 0.5 \mathrm{~kg} \mathrm{DM} /$ day in the $\mathrm{n}-3$ group compared to $14.0 \pm 0.5 \mathrm{~kg} \mathrm{DM} /$ day in the $\mathrm{n}-6$ group (Figure 1E). There was no 
309 difference in EB between groups $(-11.5 \pm 0.8$ and $-11.6 \pm 0.8 \mathrm{~kg}$ DM/day in the $\mathrm{n}-3$

310 and n-6 group, respectively, diet effect $P=0.90$ ), consistent with the absence of

311 differences for production variables between n-3 and n-6 groups, and all cows were

312 still in negative EB at 2MPP.

313 The production changes (DMI, MY and MFC) that are common with the

314 PUFA diet were not observed in the present study. Unsaturated FA are reported to 315 decrease DMI and increase MY and MFC (reviewed in Rabiee et al., 2012; Leroy et 316 al., 2014)). In a study where supplementation of dairy cow diets with fish oil 317 occurred, it was also reported that there was a tendency to increase MY in the fish oil318 treated group (Pirondini et al., 2015). It is common to find a reduction of DMI, MY 319 and changes in milk composition with feeding of the n-3 diet (Lacasse et al., 2002). 320 But with a rumen-protected form of fat, these adverse effects are less frequently 321 encountered (Lacasse et al., 2002). Most meta-analyzed studies compared fat 322 supplementation to the control diet, which was usually enriched with saturated fat to 323 provide an iso-energetic diet (Rabiee et al., 2012), making the conditions of these 324 studies different from conditions in the present study. In the present study, the control 325 diet contained n-6 PUFA, which is the most similar control for an n-3 PUFA diet. 326 Therefore, the absence of differences in production variables in the present study is 327 not surprising.

\subsection{Fat thickness and plasma metabolic variables}

To assess mobilization of the body reserve, subcutaneous adipose tissue

331 thickness and plasma NEFA concentrations were measured prepartum and throughout

332 lactation in the present study. Subcutaneous adipose tissue thickness was measured 333 from $1 \mathrm{MAP}$ to $5 \mathrm{MPP}$ and was $0.46 \pm 0.03 \mathrm{~cm}$ in the $\mathrm{n}-3$ treatment group compared 
334 with $0.47 \pm 0.02 \mathrm{~cm}$ in the n-6 treatment group (diet effect $P=0.71$; Figure $2 \mathrm{~A}$ ).

335 Plasma NEFA, glucose and urea concentrations were recorded from 4 weeks 336 antepartum (WAP-4) to 22WPP. At WPP5, plasma NEFA concentrations were greater 337 in $\mathrm{n}-3$ groups, $1.1 \pm 0.1 \mathrm{mM}$, compared with the $\mathrm{n}-6$ group, $0.8 \pm 0.1 \mathrm{mM}(P=0.039)$. 338 There were no other NEFA differences between the groups (diet effect $P=0.23$ ). 339 Plasma glucose concentrations were at WAP-4: $3.7 \pm 0.1$ and $3.9 \pm 0.1 \mathrm{mM}$ in the $\mathrm{n}-3$ 340 and n-6 groups, respectively (Figure 2B). Plasma glucose concentrations were 341 different at WPP1 $(P=0.030)$, when there was a decrease to $2.8 \pm 0.1$ and $2.4 \pm 0.1$ $342 \mathrm{mM}$ in the n-3 and n-6 groups, respectively. No other plasma glucose concentration 343 differences were detected between the groups (diet effect $P=0.42$ ). Plasma urea 344 concentrations increased continuously from WAP-4 to WPP22 (Figure 2C). There 345 was a tendency $(P=0.098)$ for increased plasma urea in the $n-3$ group at WPP2 346 compared with the $n-6$ group $(5.5 \pm 0.3$ and $4.7 \pm 0.3$, respectively). There were no 347 other urea differences between the groups (diet effect $P=0.84$ ).

The absence of differences in adipose tissue mobilization between both groups

349 is consistent with the absence of a difference in energy balance in the present study.

350 Plasma urea does not exceed the threshold that Butler et al. (1998) described at the 351 time of insemination $(19 \mathrm{mg} / \mathrm{dL}-6.8 \mathrm{mM}$ - for urea nitrogen in plasma), which can be 352 deleterious for fertility (Butler, 1998). The absence of differences in the glucose 353 concentration between the n-3 and n- 6 PUFA groups in the present study is consistent 354 with findings in a previous study comparing diets containing flaxseed and sunflower 355 seed (Ambrose et al., 2006). However, an increased glucose concentration with 356 feeding of a n-3 PUFA diet compared to a n-6 PUFA diet was also reported (Dirandeh 357 et al., 2013). 
The absence of differences in plasma NEFA concentrations when feeding the n-3 and n-6 PUFA diets is relevant (Mattos et al., 2004; Mashek et al., 2005). There are some inconsistencies in results between experiments. As reviewed by Leroy et al.

361 (2014), fat feeding and fat supplementation increased plasma NEFA as a result of 362 both DMI reduction and MY and MFC increases, consequently leading to an ovarian 363 follicular environment that was more unfavorable to cow fertility. The absence of 364 effects of dietary PUFA on production (DMI, MY, MFC) or metabolism variables 365 (glucose, NEFA) in the present study is probably related to differences in amount of 366 PUFA fed, type of dietary fat, and period of feeding of the diet (Leroy et al., 2014) 367 compared with previous studies. The diet used in the present study provided a 368 moderate amount of rumen-protected fat (1\% DM). Therefore, the lesser amount of 369 fat and/or the fact that it was rumen-protected could reduce metabolic or production 370 issues encountered when greater amounts of fat are fed. The control diet in the present 371 study was an n-6 PUFA diet. The feeding of a saturated or mono-unsaturated diet has 372 often been used as the control diet in previous studies with results being compared to 373 those obtained with the n-3 diet. These differences may explain why, in the present 374 study, there were not any effects on production or metabolic variables.

\subsection{Ovarian variables and fertility at first insemination}

The first postpartum ovulation occurred before $34.8 \pm 5.3$ days postpartum in

378 the n-3 group, and before $32.3 \pm 5.3$ days postpartum in the $n-6$ group, with no

379 difference between them (diet effect $P=0.74)$. Mean estrous cycle duration $(23.3 \pm$

3802.7 days in the $n-3$ group compared with $28.6 \pm 2.5$ days in the $n-6$ group, diet effect $381 P=0.15)$ and mean number of waves of follicular development per estrous cycle $(2.1$ 
\pm 0.2 in the n-3 group and $2.4 \pm 0.2$ waves in the n- 6 group, respectively; diet effect $P$ $=0.26)$ were also similar between groups.

Follicular growth (monitored by ultrasonographic examination of the ovaries three times a week) was analyzed from WPP3 to WPP10 (Figure 3). The total numbers of follicles during this 7 week period were $10.7 \pm 0.5$ and $10.0 \pm 0.5$ in the $n$ 3 and n-6 groups, respectively (Figure $3 \mathrm{~A}$; diet effect $P=0.26$ ). There was a trend towards increased follicle numbers at WPP8 in the n-3 group compared with the n- 6 group $(P=0.08)$. The numbers of small follicles $(\mathrm{SF})$ were $7.2 \pm 0.4$ and $6.7 \pm 0.4$ in the n-3 and n-6 groups, respectively (Figure 3B; diet effect $P=0.45$ ). The numbers of medium follicles $(\mathrm{MF})$ were $2.4 \pm 0.1$ and $2.2 \pm 0.1$ in the $n-3$ and $n-6$ groups, respectively (Figure 3C; diet effect $P=0.35$ ). There was a trend for an increased number of MF at WPP7 in the n-3 group compared with the $n-6$ group $(P=0.09)$. The numbers of large follicles (LF) tended to be greater (Figure 3D) in the n-3 group (1.2 $\pm 0.1)$ compared with the n- 6 group $(1.0 \pm 0.1$; diet effect $P=0.06)$ throughout the period studied and there was a similar trend at both WPP6 and WPP7 $(P=0.07)$. The LF group was subdivided in two subgroups, LFa $(10 \leq$ diameter $<15 \mathrm{~mm})$ and $\mathrm{LFb}$ $(15 \leq$ diameter $<25 \mathrm{~mm})$. The numbers of $\mathrm{LFa}$ were $0.8 \pm 0.0$ and $0.7 \pm 0.0$ in the $\mathrm{n}-3$ and n-6 groups, respectively, and did not differ throughout the period studied (diet effect $P=0.14$; Figure 3E). The number of LFa was greater at WPP7 in the $n-3$ group compared with the $\mathrm{n}-6$ group $(P=0.02)$. The number of $\mathrm{LFb}$ did not differ throughout the period studied between the n-3 and n-6 groups $(0.4 \pm 0.0$ and $0.3 \pm 0.0$, respectively, diet effect $P=0.31$; Figure 3F). However, the number of $L F b$ in the $n-3$ group at 4WPP tended to increase compared with the n-6 group $(P=0.09)$. The numbers of CL were $0.9 \pm 0.1$ and $0.9 \pm 0.1$ in the $n-3$ and $n-6$ groups, respectively (diet effect $P=0.74$; Figure 3G). 
408

409

410 and n-6 groups $(n=23)$. The NF-EEM tended to be less in the $n-3(13.5 \%)$ compared with the n-6 group (38.8\%, diet effect $P=0.09$, Table 5). The PLP-LEM was not different between groups: $3 / 16$ cows $(15.8 \%)$ in the $n-3$ group and 2/14 cows (14.3\%) in the n-6 group (diet effect $P=0.98$ ). No difference was observed between groups for CRAI1 (Table 5): $72.9 \%$ in the n-3 group and $48.5 \%$ in the $n-6$ group at $35 \mathrm{~d}$ (diet effect $P=0.13$ ) and $56.1 \%$ in the n-3 group and $48.1 \%$ in the n- 6 group at $90 \mathrm{~d}$ after AI1 (diet effect $P=0.63$ ). The LEM-FM was not different between groups: $3 / 16$ cows (18.7\%) in the n-3 groups and 0/12 cows (0\%) in the n-6 group (diet effect $P=0.98$ ). Moreover, there were no differences with the interval to first insemination (IFI) between groups, $80.0 \pm 5.1$ days in the $n-3$ group, compared with $84.2 \pm 5.0$ days in the n-6 group (diet effect $P=0.56$ ).

There was a trend for a decrease in NF-EEM in the n-3 group with fish oil supplementation compared to the control group in the present study. This difference is not attributable to a difference in IFI, which is similar in both groups. Rate of NFEEM of the n-6 group and rates of PLP-LEM of both n-3 and n-6 groups were consistent with results from previous studies, between $20 \%$ and $40 \%$ and between $8 \%$ and 17.5\%, respectively (Humblot, 2001; Diskin et al., 2011; Walsh et al., 2011).

These tendencies are consistent with results from previous studies that suggested a potential effect of the n-3 PUFA diet on reproductive variables: an increase in the number of small (Bilby et al., 2006c; Zachut et al., 2010) and medium follicles (Petit et al., 2002) and a trend for decreasing NF-EEM (Ambrose et al., 2006; Petit and Benchaar, 2007; Dirandeh et al., 2013). The differences in numbers of follicles were moderate in the present study, but this finding was expected, as the n- 6 
431 PUFA diet also affected follicle number in previous research (reviewed in Leroy et 432 al., 2014).

Moreover, the experimental design in the present study was meant to focus on

434 oocyte quality, consequently affecting fertilization and/or early embryo development.

435 The diet was provided between calving and 2MPP, thus during folliculogenesis in

436 follicles from which ovulation of oocytes could occur around the time of AI. Potential

437 consequences on oocyte quality can be observed by assessing pregnancy status $21 \mathrm{~d}$

438 and $35 \mathrm{~d}$ after AI1 to estimate the rates of NF-EEM and PLP-LEM. Pregnancy

439 failures occurring after $24 \mathrm{~d}$ post-AI1 (late embryo or early fetal mortality) are not 440 associated with oocyte quality (Diskin and Morris, 2008; Walsh et al., 2011).

441 Thus, in the present study, benefits of fish oil on NF-EEM could be through 442 oocyte quality enhancement, as hypothesized in the literature (reviewed in Leroy et 443 al., 2014). For example, feeding of an ALA-rich n-3 diet appears to be a satisfactory 444 approach for improving oocyte quality in dairy cows (Moallem et al., 2013). These 445 potential beneficial effects could be amplified as a result of previously described 446 physiologic mechanisms (lesser amounts of PGF2 $\alpha$, uterine progesterone receptor 447 gene expression increase) that could provide a more favorable uterine environment 448 (Mattos et al., 2004; Bilby et al., 2006a).

$449 \quad$ Fertility at first service can be affected by milk production and metabolic 450 variables which did not occur in the present experiment, where all production and 451 metabolic variables analyzed were similar between groups and not affected by the n-3 452 PUFA diet. However, these data suggest that DHA and EPA provided by the diet 453 might exert direct and specific actions on ovarian function independent of the 454 metabolic and/or production variables. 
The difference in NF-EEM between groups was notable but not significant.

456 One explanation is that the treatments imposed on both groups were expected to have

457 beneficial effects on reproduction. This was expected because the n-6 PUFA diet was 458 reported to reduce embryo mortality (Petit and Benchaar, 2007), to increase the 459 number of small (Ponter et al., 2006) and large follicles and estradiol concentrations 460 in the follicular fluid (Zachut et al., 2010) and increase the size of the dominant 461 follicle (Robinson et al., 2002). Feeding a more unsaturated source of FA improved 462 fertilization and embryo development in lactating dairy cows while the metabolic 463 status of the experimental animals was not changed (Cerri et al., 2009). The n-6 464 PUFA diet is, however, the most desirable control group for the n-3 PUFA diet 465 treatment as both contain polyunsaturated fatty acids, thus a difference in response between groups would indicate a specific effect of $n-3$ fatty acids. A comparison with a saturated diet will not allow for the discrimination between a beneficial effect of an unsaturated source compared with a PUFA source or a specific effect of n-3 fatty acids. The inclusion of the n-6 PUFA dietary treatment in the present study, as a result of positive effects on reproductive variables, made it more difficult to ascertain the beneficial n-3 dietary effects. Instead of using fish oil to provide EPA and DHA to dairy cows, another strategy could be used by supplying DHA from microalgae, which appears to replace at least in part the DHA from fish oil without leading to any

474 adverse effect on production (Abughazaleh et al., 2009).

\section{Conclusion}

In the present research, effects were studied of a n-3 PUFA diet on production, metabolic and ovarian variables of dairy cows. No differences in production and 
with the control n-6 PUFA diet. An interesting finding in the present study is that the

481 feeding of the n-3 PUFA diet tended to increase the number of large follicles and

482 decrease the non-fertilization and/or early embryo mortality rate. Nevertheless, the

483 conception rate at 35 and $90 \mathrm{~d}$ after AI1 was not affected by diet in the present study.

484 These effects do not appear to be related to production and metabolic variables.

485 Effects could, however, be associated with n-3 PUFA-specific dietary effects on the reproductive environment, with the supplementation period used (first 2 months postpartum) suggesting a potential effect on oocyte quality. Further studies are necessary to determine whether DHA or EPA enhances fertility in lactating dairy cattle and to investigate the mechanisms involved.

490

\section{Declaration of Interest}

The authors declare that there is no conflict of interest that could be perceived as prejudicing the impartiality of the research reported.

494

495

\section{Acknowledgements}

The INRA (Institut National de la Recherche Agronomique), ApisGene and Région Centre Val de Loire financially supported this work. We would like to thank the technical staff of the research (PRC) and experimental (UEPAO) units in INRA Nouzilly (Christelle Ramé, Mickael Delanoue, Christophe Mouaze, Ludovic Métivier and Damien Capo) and two students (Sonia Roger and Anaïs Leport) who helped during experiment work and data analysis. The authors also acknowledge Thibaud Le Mouel, Marie Le Tilly and Colette Mustiere at the INRA Rennes for the NEFA and 
503 glucose assays, as well as Melanie Collin and Anne-Sophie Gross at the Institut

504 Gustave Roussy for the fatty acid composition analysis in plasma.

505

506 


\section{References}

Abughazaleh, A.A., Potu, R.B., Ibrahim, S., 2009. Short communication: The effect of substituting fish oil in dairy cow diets with docosahexaenoic acid-micro algae on milk composition and fatty acids profile. J. Dairy Sci. 92, 6156-6159.

Ambrose, D.J., Kastelic, J.P., Corbett, R., Pitney, P.A., Petit, H.V., Small, J.A., Zalkovic, P., 2006. Lower pregnancy losses in lactating dairy cows fed a diet enriched in alpha-linolenic acid. J. Dairy Sci. 89, 3066-3074.

Ashes, J.R., Siebert, B.D., Gulati, S.K., Cuthbertson, A.Z., Scott, T.W., 1992. Incorporation of $n-3$ fatty acids of fish oil into tissue and serum lipids of ruminants. Lipids 27, 629-631.

Bernard, L., Shingfield, K.J., Rouel, J., Ferlay, A., Chilliard, Y., 2009. Effect of plant oils in the diet on performance and milk fatty acid composition in goats fed diets based on grass hay or maize silage. Br. J. Nutr. 101, 213-224.

Bilby, T.R., Guzeloglu, A., MacLaren, L.A., Staples, C.R., Thatcher, W.W., 2006a. Pregnancy, bovine somatotropin, and dietary n-3 fatty acids in lactating dairy cows: II. Endometrial gene expression related to maintenance of pregnancy. J. Dairy Sci. 89, 3375-3385.

Bilby, T.R., Jenkins, T., Staples, C.R., Thatcher, W.W., 2006b. Pregnancy, bovine somatotropin, and dietary n-3 fatty acids in lactating dairy cows: III. Fatty acid distribution. J. Dairy Sci. 89, 3386-3399.

Bilby, T.R., Sozzi, A., Lopez, M.M., Silvestre, F.T., Ealy, A.D., Staples, C.R., Thatcher, W.W., 2006c. Pregnancy, bovine somatotropin, and dietary n-3 fatty acids in lactating dairy cows: I. Ovarian, conceptus, and growth hormoneinsulin-like growth factor system responses. J. Dairy Sci. 89, 3360-3374.

Burdge, G.C., Calder, P.C., 2005. Conversion of alpha-linolenic acid to longer-chain polyunsaturated fatty acids in human adults. Reprod. Nutr. Dev. 45, 581-597.

Butler, W.R., 1998. Review: effect of protein nutrition on ovarian and uterine physiology in dairy cattle. J. Dairy Sci. 81, 2533-2539.

Butler, W.R., 2000. Nutritional interactions with reproductive performance in dairy cattle. Anim. Reprod. Sci. 60-61, 449-457.

Calder, P.C., 2012. Mechanisms of action of (n-3) fatty acids. J. Nutr. 142, 592S599S.

Canepa, S., Laine, A.B., A., Fagu, C., Flon, C., Monniaux, D., 2008. Validation d'une methode immunoenzymatique pour le dosage de la progesterone dans le plasma des ovins et des bovins. Les Cahiers Techniques de L'INRA 64, 19-30.

Cant, J.P., Fredeen, A.H., MacIntyre, T., Gunn, J., Crowe, N., 1997. Effect of fish oil and monensin on milk composition in dairy cows. Can. J. Anim. Sci. 77, 125131.

Castaneda-Gutierrez, E., de Veth, M.J., Lock, A.L., Dwyer, D.A., Murphy, K.D., Bauman, D.E., 2007. Effect of supplementation with calcium salts of fish oil on n-3 fatty acids in milk fat. J. Dairy Sci. 90, 4149-4156.

Cerri, R.L., Juchem, S.O., Chebel, R.C., Rutigliano, H.M., Bruno, R.G., Galvao, K.N., Thatcher, W.W., Santos, J.E., 2009. Effect of fat source differing in fatty acid profile on metabolic parameters, fertilization, and embryo quality in highproducing dairy cows. J. Dairy Sci. 92, 1520-1531.

Chajes, V., Thiebaut, A.C., Rotival, M., Gauthier, E., Maillard, V., Boutron-Ruault, M.C., Joulin, V., Lenoir, G.M., Clavel-Chapelon, F., 2008. Association between serum trans-monounsaturated fatty acids and breast cancer risk in the E3N-EPIC Study. Am. J. Epidemiol. 167, 1312-1320. 
Coyral-Castel, S., Brisard, D., Touze, J.L., Dupont, M., Rame, C., Uzbekova, S., Dupont, J., 2012a. Analysis of in vivo oocyte maturation, in vitro embryo development and gene expression in cumulus cells of dairy cows and heifers selected for one fertility quantitative trait loci (QTL) located on BTA3. Theriogenology 77, 1822-1833.e1821.

Coyral-Castel, S., Faverdin, P., Ramé, C., Fréret, S., Guillaume, D., Fritz, S., Dupont, J., 2012b. Significant differences in fertility between dairy cows selected for one QTL located on bovine chromosome 3 are not attributable to energy balance, although eating behaviour is affected. Animal 7, 610-617.

Coyral-Castel, S., Ramé, C., Monniaux, D., Fréret, S., Fabre-Nys, C., Fritz, S., Monget, P., Dupont, F., Dupont, J., 2011. Ovarian parameters and fertility of dairy cows selected for one QTL located on BTA3. Theriogenology 75, 12391250.

Deckelbaum, R.J., Torrejon, C., 2012. The omega-3 fatty acid nutritional landscape: health benefits and sources. J. Nutr. 142, 587S-591S.

Dirandeh, E., Towhidi, A., Zeinoaldini, S., Ganjkhanlou, M., Ansari Pirsaraei, Z., Fouladi-Nashta, A., 2013. Effects of different polyunsaturated fatty acid supplementations during the postpartum periods of early lactating dairy cows on milk yield, metabolic responses, and reproductive performances. J. Anim. Sci. 91, 713-721.

Diskin, M.G., Morris, D.G., 2008. Embryonic and Early Foetal Losses in Cattle and Other Ruminants. Reprod. Domest. Anim. 43, 260-267.

Diskin, M.G., Parr, M.H., Morris, D.G., 2011. Embryo death in cattle: an update. Reprod. Fertil. Dev. 24, 244-251.

Humblot, P., 2001. Use of pregnancy specific proteins and progesterone assays to monitor pregnancy and determine the timing, frequencies and sources of embryonic mortality in ruminants. Theriogenology 56, 1417-1433.

Hutchinson, I.A., Hennessy, A.A., Waters, S.M., Dewhurst, R.J., Evans, A.C.O., Lonergan, P., Butler, S.T., 2012. Effect of supplementation with different fat sources on the mechanisms involved in reproductive performance in lactating dairy cattle. Theriogenology 78, 12-27.

INRA, 2007. Alimentation des bovins, ovins et caprins : Besoins des animaux Valeurs des aliments, Paris, France : Quae editions.

Lacasse, P., Kennelly, J.J., Delbecchi, L., Ahnadi, C.E., 2002. Addition of protected and unprotected fish oil to diets for dairy cows. I. Effects on the yield, composition and taste of milk. J. Dairy Res. 69, 511-520.

Leroy, J., Sturmey, R.G., Van Hoeck, V., De Bie, J., McKeegan, P.J., Bols, P.E.J., 2014. Dietary fat supplementation and the consequences for oocyte and embryo quality: hype or significant benefit for dairy cow reproduction? Reprod. Domest. Anim. 49, 353-361.

Leroy, J.L., Vanholder, T., Van Knegsel, A.T., Garcia-Ispierto, I., Bols, P.E., 2008. Nutrient prioritization in dairy cows early postpartum: mismatch between metabolism and fertility? Reprod. Domest. Anim. 43 Suppl 2, 96-103.

Lucy, M.C., Savio, J.D., Badinga, L., De La Sota, R.L., Thatcher, W.W., 1992. Factors that affect ovarian follicular dynamics in cattle. J. Anim. Sci. 70, 3615-3626.

Mashek, D.G., Bertics, S.J., Grummer, R.R., 2005. Effects of intravenous triacylglycerol emulsions on hepatic metabolism and blood metabolites in fasted dairy cows. J. Dairy Sci. 88, 100-109. 
Mattos, R., Staples, C.R., Arteche, A., Wiltbank, M.C., Diaz, F.J., Jenkins, T.C., Thatcher, W.W., 2004. The effects of feeding fish oil on uterine secretion of PGF2alpha, milk composition, and metabolic status of periparturient Holstein cows. J. Dairy Sci. 87, 921-932.

Mattos, R., Staples, C.R., Thatcher, W.W., 2000. Effects of dietary fatty acids on reproduction in ruminants. Rev. Reprod. 5, 38-45.

Moallem, U., Shafran, A., Zachut, M., Dekel, I., Portnick, Y., Arieli, A., 2013. Dietary alpha-linolenic acid from flaxseed oil improved folliculogenesis and IVF performance in dairy cows, similar to eicosapentaenoic and docosahexaenoic acids from fish oil. Reproduction 146, 603-614.

Petit, H.V., Benchaar, C., 2007. Importance of dietary fat on reproduction of dairy cows. Renc. Rech. Ruminants 14, 329-332.

Petit, H.V., Dewhurst, R.J., Scollan, N.D., Proulx, J.G., Khalid, M., Haresign, W., Twagiramungu, H., Mann, G.E., 2002. Milk production and composition, ovarian function, and prostaglandin secretion of dairy cows fed omega-3 fats. J. Dairy Sci. 85, 889-899.

Petit, H.V., Twagiramungu, H., 2006. Conception rate and reproductive function of dairy cows fed different fat sources. Theriogenology 66, 1316-1324.

Pirondini, M., Colombini, S., Mele, M., Malagutti, L., Rapetti, L., Galassi, G., Crovetto, G.M., 2015. Effect of dietary starch concentration and fish oil supplementation on milk yield and composition, diet digestibility, and methane emissions in lactating dairy cows. J. Dairy Sci. 98, 357-372.

Plourde, M., Cunnane, S.C., 2007. Extremely limited synthesis of long chain polyunsaturates in adults: implications for their dietary essentiality and use as supplements. Appl. Physiol. Nutr. Metab. 32, 619-634.

Ponter, A.A., Arnault, J., Guelou, K., Ponchon, S., Gonzales, C., Grimard, B., Humblot, P., 2006. Effect of the type of dietary fatty acid ( $\alpha$-linolenic acid or linoleic acid) on the number and the quality of oocytes collected by Ovum Pick-Up and on the production of embryos by dairy heifers. Renc. Rech. Ruminants 13, 289.

Rabiee, A.R., Breinhild, K., Scott, W., Golder, H.M., Block, E., Lean, I.J., 2012. Effect of fat additions to diets of dairy cattle on milk production and components: a meta-analysis and meta-regression. J. Dairy Sci. 95, 32253247.

Robinson, R.S., Pushpakumara, P.G., Cheng, Z., Peters, A.R., Abayasekara, D.R., Wathes, D.C., 2002. Effects of dietary polyunsaturated fatty acids on ovarian and uterine function in lactating dairy cows. Reproduction 124, 119-131.

Roche, J.F., 2006. The effect of nutritional management of the dairy cow on reproductive efficiency. Anim. Reprod. Sci. 96, 282-296.

SAS institute Inc., 2011. SAS/STAT 9.2 user's Guide, Second edition. Cary, NC: SAS institute Inc.

Schroder, U.J., Staufenbiel, R., 2006. Invited review: Methods to determine body fat reserves in the dairy cow with special regard to ultrasonographic measurement of backfat thickness. J. Dairy Sci. 89, 1-14.

Simopoulos, A.P., 2002. Omega-3 fatty acids in inflammation and autoimmune diseases. J. Am. Coll. Nutr. 21, 495-505.

Sirois, J., Fortune, J.E., 1988. Ovarian follicular dynamics during the estrous cycle in heifers monitored by real-time ultrasonography. Biol. Reprod. 39, 308-317. 
653

654

655

656

657

658

659

660

661

662

663

664

665

666

667

668

669

670

671
Staples, C.R., Burke, J.M., Thatcher, W.W., 1998. Influence of supplemental fats on reproductive tissues and performance of lactating cows. J. Dairy Sci. 81, 856871.

Tessaro, F.H., Ayala, T.S., Martins, J.O., 2015. Lipid Mediators Are Critical in Resolving Inflammation: A Review of the Emerging Roles of Eicosanoids in Diabetes Mellitus. Biomed Res Int 2015, 568408.

Urlep, Z., Rozman, D., 2013. The Interplay between Circadian System, Cholesterol Synthesis, and Steroidogenesis Affects Various Aspects of Female Reproduction. Front Endocrinol (Lausanne) 4, 111.

Walsh, S.W., Williams, E.J., Evans, A.C., 2011. A review of the causes of poor fertility in high milk producing dairy cows. Anim. Reprod. Sci. 123, 127-138.

Zachut, M., Dekel, I., Lehrer, H., Arieli, A., Arav, A., Livshitz, L., Yakoby, S., Moallem, U., 2010. Effects of dietary fats differing in n-6:n-3 ratio fed to high-yielding dairy cows on fatty acid composition of ovarian compartments, follicular status, and oocyte quality. J. Dairy Sci. 93, 529-545. 
672

673

674 Fig. 1. Production variables - Body weight (A) and milk yield (B) were monitored

675 during 22 weeks postpartum over two lactations (n-3, $n=23 ; n-6, n=23)$. Milk fat

676 content (C), milk protein content (D) were monitored during 22 weeks postpartum 677 over the first lactation only $(\mathrm{n}-3, n=12 ; \mathrm{n}-6, n=12)$. Dry matter intake (E) and 678

682

683

684

685

686

687

688

689

690

691

692

693

694 Fig. 3. Ovarian follicular dynamics - Total number of follicles (A), the number of 695 696 energy balance $(\mathrm{F})$ were monitored during 8 weeks postpartum over two lactations (n$3, n=23 ; \mathrm{n}-6, n=23$ ). Cows received either the $\mathrm{n}-3$ diet (black line) or the $\mathrm{n}-6$ diet (grey line) from calving to 2 months postpartum. Results are presented as lsmeans +/SEM. *indicates a difference $(P<0.05)$; ${ }^{*}$ indicates a tendency $(P<0.10)$

Fig. 2. Subcutaneous adipose tissue thickness and metabolic variables - Adipose tissue mobilization was assessed through subcutaneous fat thickness measurements in the sacral region using ultrasonographic examination at 1 month antepartum (1MAP), 2 weeks postpartum (2WPP), 1 month postpartum (1MPP), 2 months postpartum (2MPP) and 5 months postpartum (5MPP) (A). Plasma NEFA (B), glucose (C) and urea (D) levels were monitored once a week, from 4 weeks antepartum to 22 weeks postpartum. Cows were monitored over two lactations and received either the n-3 diet (black line, $n=23$ ) or the n-6 diet (grey line, $n=23$ ) from calving to 2MPP. Results are presented as lsmeans +/- SEM. *indicates a difference $(P<0.05)$; ${ }_{\text {indicates a }}$ tendency $(P<0.10)$.

small (B), medium (C) and large (D) follicles as well as the number of CL (G) were recorded from WPP3 to WPP10. The large follicle category was subdivided into 
697 follicles between 10 and $15 \mathrm{~mm}$ (E) and follicles between 15 and $25 \mathrm{~mm}(\mathrm{~F})$. Cows 698 were monitored over two lactations and received either the n-3 diet (black line, $n=$ 69923 ) or the n-6 diet (grey line, $n=23$ ) from calving to 2 months postpartum. Results

700 are presented as lsmeans $+/$ - SEM. *indicates a difference $(P<0.05)$; indicates a 701 tendency $(P<0.10)$

702

703

704

705 
Table 1: Number of cows per diet group and per year

\begin{tabular}{cccc}
\hline Diet & Year 1 & Year 2 & Total \\
\hline $\mathrm{n}-3$ & 13 & 10 & 23 \\
$\mathrm{n}-6$ & 12 & 11 & 23 \\
\hline Total & 25 & 21 & 46 \\
\hline
\end{tabular}

$\mathrm{n}-3, \mathrm{n}-3$ polyunsaturated fatty acids; $n-6, n-6$ polyunsaturated fatty acids

Table 2: Ingredients composing the experimental diets, and nutritional composition of the diets (mean \pm SEM, $n=3$ samples)

\begin{tabular}{lcc}
\hline & \multicolumn{2}{c}{ Diet from calving to 2MPP } \\
& n-3 & n-6 \\
\hline Ingredient (\% DM): & 65.7 & 65.1 \\
corn silage & 8.3 & 8.3 \\
dehydrated alfalfa & 10.3 & 10.2 \\
Sandifort® (wheat) & 13.7 & 13.6 \\
Sandilait® (soybean and rapeseed meal) & 0.6 & 0.6 \\
Vitamins and minerals 5/23 & 0.4 & 0.4 \\
calcium bicarbonate & 1 & \\
encapsulated fish oil & & 1.8 \\
toasted soybeans & & \\
& & \\
DM, \% & $38.8 \pm 1.6$ & $38.4 \pm 1.3$ \\
NE, MJ/kg DM & $6.9 \pm 0.1$ & $7.0 \pm 0.1$ \\
PDIE, g/kg DM & $91.3 \pm 4.0$ & $88.9 \pm 4.4$ \\
PDIN, g/kg DM & $89.0 \pm 6.6$ & $86.1 \pm 7.5$ \\
Neutral detergent fiber, \% & $32.0 \pm 1.0$ & $32.0 \pm 1.4$ \\
Acid detergent fiber, \% & $20.8 \pm 0.7$ & $20.5 \pm 0.9$ \\
Crude protein, \% & $12.8 \pm 0.9$ & $12.3 \pm 1.0$ \\
Fat, \% & $2.8 \pm 0.2$ & $2.7 \pm 0.1$ \\
\hline
\end{tabular}

n-3, n-3 polyunsaturated fatty acids; $n-6, n-6$ polyunsaturated fatty acids; $2 \mathrm{MPP}$, two months postpartum; DM, dry matter; $\mathrm{NE}_{\mathrm{L}}$, net energy for maintenance and lactation; PDIE, intestinal digestible proteins, when Energy is the limiting factor of microbial synthesis; PDIN, intestinal digestible proteins, when degraded $\mathrm{N}$ is the limiting factor of microbial synthesis 
Table 3: Effect of n-3 ( $n=13)$ or $n-6$ diet $(n=16)$ on plasma fatty acid composition (\% of total fatty acid), expressed as lsmeans \pm SEM

\begin{tabular}{|c|c|c|c|c|c|c|c|c|}
\hline & & & & Stage & ind diet & & & \\
\hline & & IAP & & PP & & IPP & & IPP \\
\hline & $n-3$ & $n-6$ & $n-3$ & $n-6$ & $n-3$ & $n-6$ & $n-3$ & $n-6$ \\
\hline C15:0 & $0.42 \pm 0.01 \mathrm{a}$ & $0.40 \pm 0.01 \mathrm{a}$ & $0.25 \pm 0.01 \mathrm{a}$ & $0.21 \pm 0.01 \mathrm{~b}$ & $0.34 \pm 0.01 \mathrm{a}$ & $0.29 \pm 0.01 b$ & $0.36 \pm 0.02 \mathrm{a}$ & $0.33 \pm 0.01 \mathrm{a}$ \\
\hline $\mathrm{C} 17: 0$ & $2.73 \pm 0.22 \mathrm{a}$ & $3.35 \pm 0.21 b$ & $0.92 \pm 0.22 \mathrm{a}$ & $0.83 \pm 0.21 \mathrm{a}$ & $1.77 \pm 0.24 \mathrm{a}$ & $1.62 \pm 0.22 \mathrm{a}$ & $2.62 \pm 0.33 \mathrm{a}$ & $2.32 \pm 0.26 \mathrm{a}$ \\
\hline SFA & $42.55 \pm 0.37 \mathrm{a}$ & $42.75 \pm 0.35 \mathrm{a}$ & $39.75 \pm 0.37 \mathrm{a}$ & $39.63 \pm 0.35 \mathrm{a}$ & $39.25 \pm 0.41 \mathrm{a}$ & $39.58 \pm 0.36 a$ & $41.08 \pm 0.55 \mathrm{a}$ & $40.15 \pm 0.43 a$ \\
\hline C14:1 & $0.11 \pm 0.01 \mathrm{a}$ & $0.09 \pm 0.01 b$ & $0.07 \pm 0.01 \mathrm{a}$ & $0.06 \pm 0.01 \mathrm{a}$ & $0.07 \pm 0.01 \mathrm{a}$ & $0.07 \pm 0.01 \mathrm{a}$ & $0.07 \pm 0.01 \mathrm{a}$ & $0.07 \pm 0.01 \mathrm{a}$ \\
\hline C16:1 & $1.68 \pm 0.09 \mathrm{a}$ & $1.53 \pm 0.09 \mathrm{a}$ & $2.08 \pm 0.09 \mathrm{a}$ & $1.81 \pm 0.09 b$ & $1.35 \pm 0.10 \mathrm{a}$ & $1.28 \pm 0.09 \mathrm{a}$ & $0.80 \pm 0.12 \mathrm{a}$ & $1.01 \pm 0.10 \mathrm{a}$ \\
\hline C18:1 & $18.74 \pm 0.62 \mathrm{a}$ & $18.38 \pm 0.58 \mathrm{a}$ & $22.97 \pm 0.62 \mathrm{a}$ & $22.86 \pm 0.58 \mathrm{a}$ & $19.05 \pm 0.67 \mathrm{a}$ & $20.96 \pm 0.6 \mathrm{~b}$ & $15.43 \pm 0.89 a$ & $17.84 \pm 0.71 b$ \\
\hline MUFA & $22.00 \pm 0.65 \mathrm{a}$ & $21.30 \pm 0.60 \mathrm{a}$ & $26.04 \pm 0.65 \mathrm{a}$ & $25.62 \pm 0.60 \mathrm{a}$ & $21.46 \pm 0.70 a$ & $23.29 \pm 0.63 \mathrm{a}$ & $17.21 \pm 0.92 \mathrm{a}$ & $19.76 \pm 0.73 b$ \\
\hline C18:2n-6 & $16.58 \pm 0.63 a$ & $17.35 \pm 0.58 a$ & $19.33 \pm 0.63 \mathrm{a}$ & $21.55 \pm 0.58 b$ & $23.93 \pm 0.68 \mathrm{a}$ & $23.68 \pm 0.61 \mathrm{a}$ & $26.86 \pm 0.91 \mathrm{a}$ & $25.00 \pm 0.72 \mathrm{a}$ \\
\hline C20:2n-6 & $0.17 \pm 0.01 \mathrm{a}$ & $0.16 \pm 0.01 \mathrm{a}$ & $0.09 \pm 0.01 \mathrm{a}$ & $0.08 \pm 0.01 \mathrm{a}$ & $0.17 \pm 0.01 \mathrm{a}$ & $0.13 \pm 0.01$ b & $0.19 \pm 0.01 \mathrm{a}$ & $0.18 \pm 0.01 \mathrm{a}$ \\
\hline C20:3n-6 & $4.30 \pm 0.19 \mathrm{a}$ & $4.77 \pm 0.18 \mathrm{a}$ & $2.22 \pm 0.19 \mathrm{a}$ & $2.37 \pm 0.18 \mathrm{a}$ & $2.45 \pm 0.21 \mathrm{a}$ & $3.63 \pm 0.18 b$ & $5.28 \pm 0.27 \mathrm{a}$ & $4.92 \pm 0.22 \mathrm{a}$ \\
\hline C20:3n-9 & $0.22 \pm 0.02 \mathrm{a}$ & $0.26 \pm 0.02 \mathrm{a}$ & $0.17 \pm 0.02 \mathrm{a}$ & $0.18 \pm 0.02 \mathrm{a}$ & $0.14 \pm 0.02 \mathrm{a}$ & $0.21 \pm 0.02 b$ & $0.20 \pm 0.03 \mathrm{a}$ & $0.24 \pm 0.02 \mathrm{a}$ \\
\hline C20:4n-6 & $5.57 \pm 0.17 \mathrm{a}$ & $5.22 \pm 0.16 \mathrm{a}$ & $4.53 \pm 0.17 \mathrm{a}$ & $4.39 \pm 0.16 \mathrm{a}$ & $3.29 \pm 0.19 \mathrm{a}$ & $3.69 \pm 0.17 \mathrm{a}$ & $3.53 \pm 0.25 \mathrm{a}$ & $3.91 \pm 0.20 \mathrm{a}$ \\
\hline n-6 & $28.29 \pm 0.70 \mathrm{a}$ & $29.03 \pm 0.65 \mathrm{a}$ & $27.4 \pm 0.70 \mathrm{a}$ & $29.43 \pm 0.65 b$ & $31.12 \pm 0.76 \mathrm{a}$ & $32.38 \pm 0.67 \mathrm{a}$ & $37.21 \pm 1.01 \mathrm{a}$ & $35.67 \pm 0.80 \mathrm{a}$ \\
\hline C18:3n-3 ALA & $2.76 \pm 0.09 a$ & $2.77 \pm 0.08 \mathrm{a}$ & $1.45 \pm 0.09 \mathrm{a}$ & $1.34 \pm 0.08 \mathrm{a}$ & $1.55 \pm 0.10 \mathrm{a}$ & $1.45 \pm 0.09 \mathrm{a}$ & $1.75 \pm 0.13 \mathrm{a}$ & $1.56 \pm 0.10 \mathrm{a}$ \\
\hline C20:5n-3 EPA & $1.33 \pm 0.15 \mathrm{a}$ & $1.23 \pm 0.14 \mathrm{a}$ & $1.99 \pm 0.15 a$ & $1.15 \pm 0.14 b$ & $2.57 \pm 0.16 \mathrm{a}$ & $0.91 \pm 0.14 b$ & $0.62 \pm 0.22 \mathrm{a}$ & $0.66 \pm 0.17 \mathrm{a}$ \\
\hline C22:6n-3 DHA & $0.50 \pm 0.07 \mathrm{a}$ & $0.46 \pm 0.07 \mathrm{a}$ & $0.79 \pm 0.07 a$ & $0.52 \pm 0.07 b$ & $1.42 \pm 0.08 \mathrm{a}$ & $0.32 \pm 0.07 b$ & $0.26 \pm 0.10 \mathrm{a}$ & $0.16 \pm 0.08 \mathrm{a}$ \\
\hline n-3 & $7.06 \pm 0.30 \mathrm{a}$ & $6.82 \pm 0.28 a$ & $6.69 \pm 0.30 \mathrm{a}$ & $5.19 \pm 0.28 b$ & $8.06 \pm 0.33 \mathrm{a}$ & $4.65 \pm 0.29 b$ & $4.48 \pm 0.43 \mathrm{a}$ & $4.25 \pm 0.35 \mathrm{a}$ \\
\hline PUFA & $35.35 \pm 0.72 a$ & $35.86 \pm 0.67 \mathrm{a}$ & $34.09 \pm 0.72 \mathrm{a}$ & $34.62 \pm 0.67 \mathrm{a}$ & $39.19 \pm 0.79 \mathrm{a}$ & $37.02 \pm 0.70 b$ & $41.69 \pm 1.05 \mathrm{a}$ & $39.9 \pm 0.83 \mathrm{a}$ \\
\hline ratio $n-6 / n-3$ & $5.16 \pm 0.36 \mathrm{a}$ & $5.57 \pm 0.34 \mathrm{a}$ & $5.6 \pm 0.36 \mathrm{a}$ & $7.85 \pm 0.34 b$ & $5.66 \pm 0.39 \mathrm{a}$ & $9.62 \pm 0.35 \mathrm{~b}$ & $11.28 \pm 0.52 \mathrm{a}$ & $11.78 \pm 0.42 \mathrm{a}$ \\
\hline
\end{tabular}

n-3, n-3 polyunsaturated fatty acids; $n-6, n-6$ polyunsaturated fatty acids; 1MAP, one month antepartum; 1WPP, one week postpartum; 2MPP, two months postpartum; 5MPP, five month postpartum; SFA = sum of saturated FA; MUFA = sum of monounsaturated FA; PUFA = sum of polyunsaturated FA; n-3= sum of n-3 FA; and n-6 = sum of n-6 FA; ALA, alpha linolenic acid; EPA, eicosapentaenoic acid; DHA, docosahexaenoic acid.

${ }^{\mathrm{a}-\mathrm{b}}$ Means within a row and a stage with different superscripts differ $(\mathrm{P}<0.05)$ 
Table 4: Effect of n-3 $(n=6)$ or n-6 $(n=6)$ diet on milk fatty acid composition at stage 2MPP during the $1^{\text {st }}$ year of experiment (\% of total fatty acid), expressed as means \pm SEM

\begin{tabular}{|c|c|c|c|}
\hline \multirow[b]{2}{*}{ Milk FA \% } & \multicolumn{2}{|c|}{ Diet } & Diet effect \\
\hline & $n-3$ & $n-6$ & P-Value \\
\hline $\mathrm{C} 14: 0$ & $9.54 \pm 0.48 \mathrm{a}$ & $9.41 \pm 0.64 \mathrm{a}$ & 0.88 \\
\hline C15:0 & $1.29 \pm 0.13 a$ & $0.95 \pm 0.06 b$ & 0.04 \\
\hline C16:0 & $28.38 \pm 1.47 \mathrm{a}$ & $30.29 \pm 1.23 \mathrm{a}$ & 0.34 \\
\hline SFA & $59.38 \pm 2.21 \mathrm{a}$ & $62.73 \pm 1.77 \mathrm{a}$ & 0.26 \\
\hline C18:1 & $29.03 \pm 1.91 \mathrm{a}$ & $27.61 \pm 1.72 \mathrm{a}$ & 0.59 \\
\hline C20:1 & $0.13 \pm 0.01 a$ & $0.09 \pm 0.00 \mathrm{~b}$ & 0.03 \\
\hline C22:1 & $0.04 \pm 0.01 a$ & $0.02 \pm 0.00 b$ & 0.04 \\
\hline MUFA & $33.4 \pm 2.01 \mathrm{a}$ & $31.46 \pm 1.64 \mathrm{a}$ & 0.47 \\
\hline C18:2 & $2.52 \pm 0.11 \mathrm{a}$ & $2.23 \pm 0.11 \mathrm{a}$ & 0.09 \\
\hline C20:2n-6 & $0.04 \pm 0.00 a$ & $0.03 \pm 0.00 b$ & 0.02 \\
\hline C20:3n-6 & $0.06 \pm 0.00 a$ & $0.07 \pm 0.01 b$ & 0.03 \\
\hline n-6 & $2.74 \pm 0.12 \mathrm{a}$ & $2.46 \pm 0.11 \mathrm{a}$ & 0.13 \\
\hline C18:3n-3 ALA & $0.42 \pm 0.02 a$ & $0.33 \pm 0.02 b$ & 0.01 \\
\hline C20:5n-3 EPA & $0.10 \pm 0.02 a$ & $0.03 \pm 0.00 b$ & 0.02 \\
\hline C22:6n-3 DHA & $0.07 \pm 0.02 a$ & $0.02 \pm 0.00 b$ & 0.03 \\
\hline n-3 & $0.74 \pm 0.08 a$ & $0.45 \pm 0.02 b$ & 0.01 \\
\hline PUFA & $3.48 \pm 0.17 a$ & $2.91 \pm 0.14 b$ & 0.03 \\
\hline CLA & $0.81 \pm 0.09 a$ & $0.51 \pm 0.02 b$ & 0.02 \\
\hline
\end{tabular}

n-3, n-3 polyunsaturated fatty acids; $n-6, n-6$ polyunsaturated fatty acids; 2 MPP, two months postpartum ;SFA = sum of saturated FA; MUFA = sum of monounsaturated FA; PUFA = sum of polyunsaturated FA; n-3= sum of n-3 FA; n- $6=$ sum of n-6 FA; and CLA = conjugated linoleic acid; ALA, alpha linolenic acid; EPA, eicosapentaenoic acid; DHA, docosahexaenoic acid.

${ }^{\mathrm{a}-\mathrm{b}}$ Means within a row with different superscripts differ $(\mathrm{P}<0.05)$ 
Table 5: Effect of n-3 $(n=22)$ or $n-6(n=23)$ diet on NF-EEM and CRAI1 (expressed as estimated \%)

\begin{tabular}{|c|c|c|c|c|}
\hline & \multicolumn{2}{|c|}{ Diet } & \multicolumn{2}{|l|}{ Diet effect } \\
\hline & $n-3$ & $n-6$ & OR $(95 \%$ confidence interval $)$ & P-value \\
\hline NF-EEM & $13.50 \%$ & $38.80 \%$ & $0.245(0.049-1.229)$ & 0.086 \\
\hline CRAI1 35 d after AI1 & $72.90 \%$ & $48.50 \%$ & $2.861(0.726-11.279)$ & 0.129 \\
\hline CRAI1 90 d after AI1 & $56.10 \%$ & $48.10 \%$ & $1.377(0.365-5.198)$ & 0.629 \\
\hline
\end{tabular}


A. Body weight ( $\mathrm{kg})$

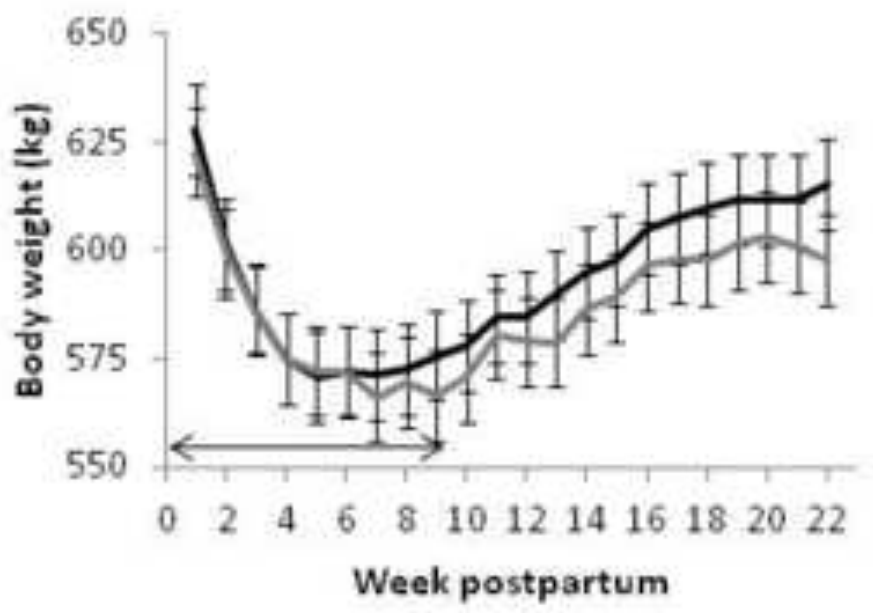

C. Milk fat content $(\mathrm{g} / \mathrm{L})$

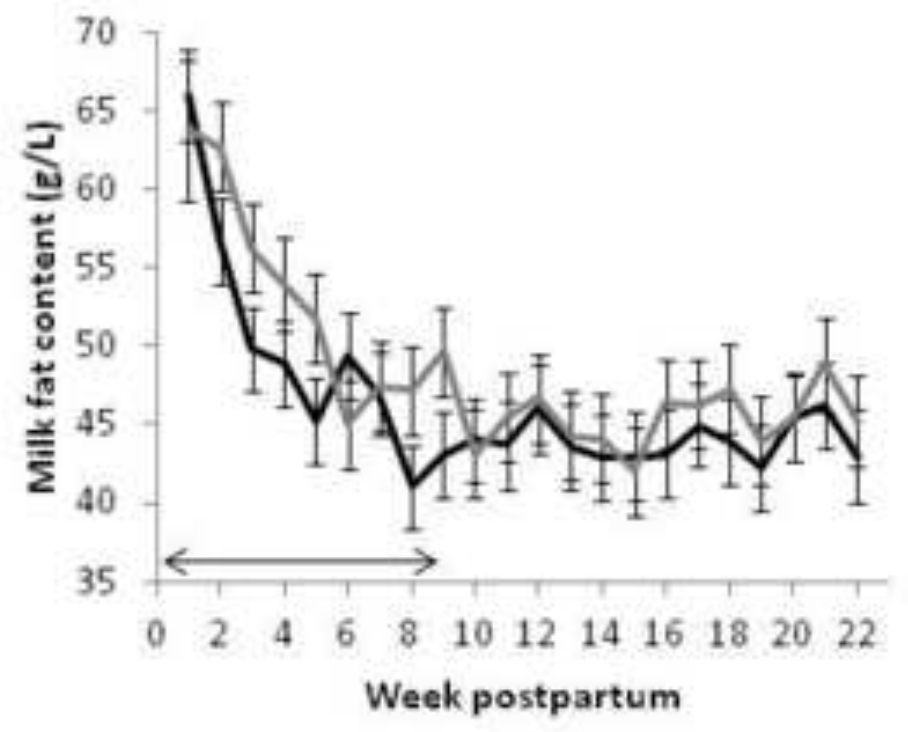

E. Dry matter intake $(\mathrm{kg} / \mathrm{d})$

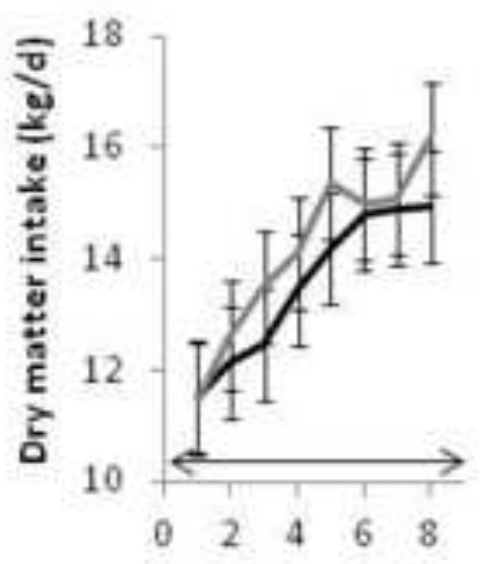

Week postpartum
B. Milk yield $(\mathrm{kg} / \mathrm{d})$

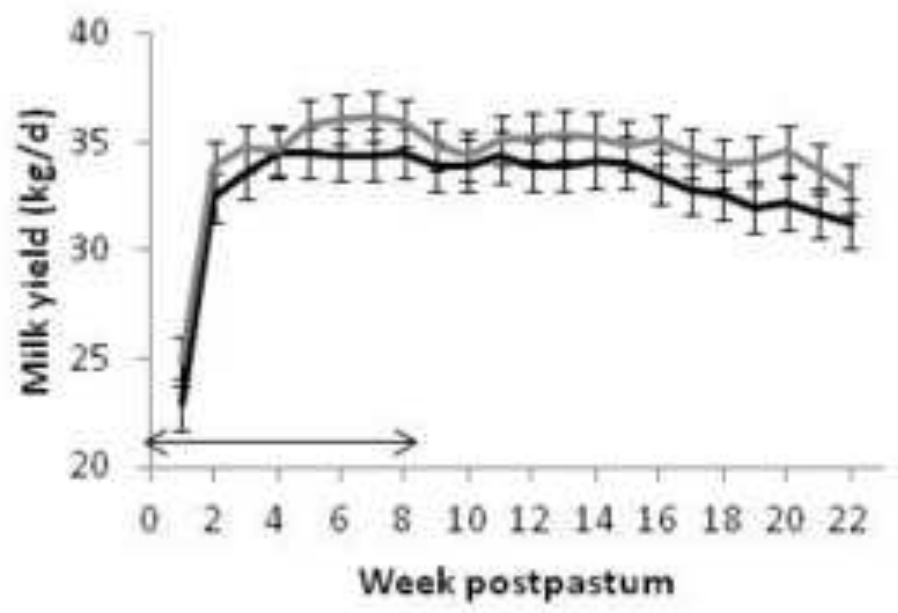

D. Milk protein content $(\mathrm{g} / \mathrm{L})$

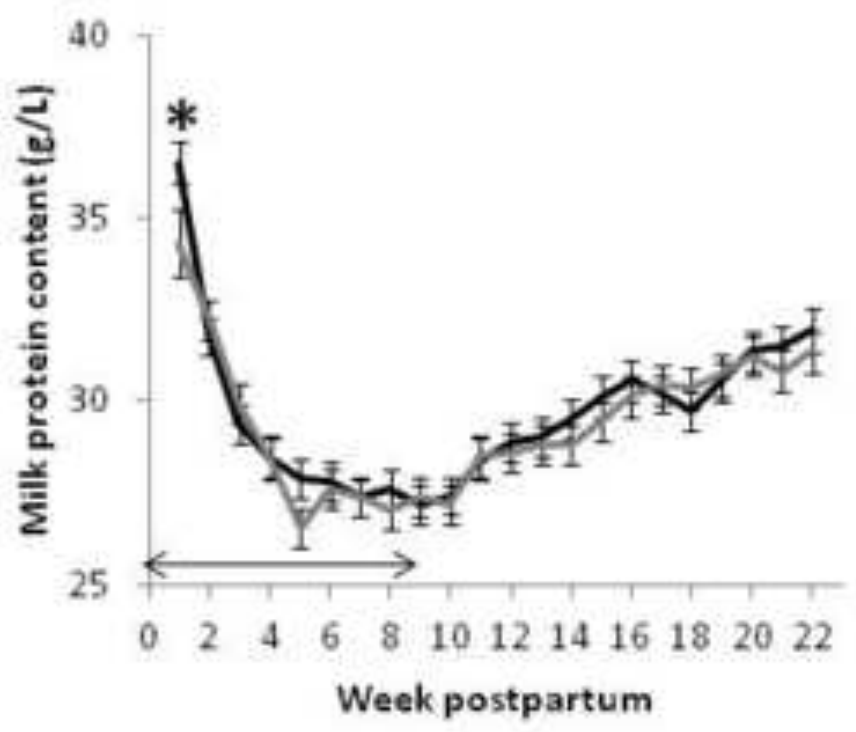

F. Energy balance (Mcal/d)

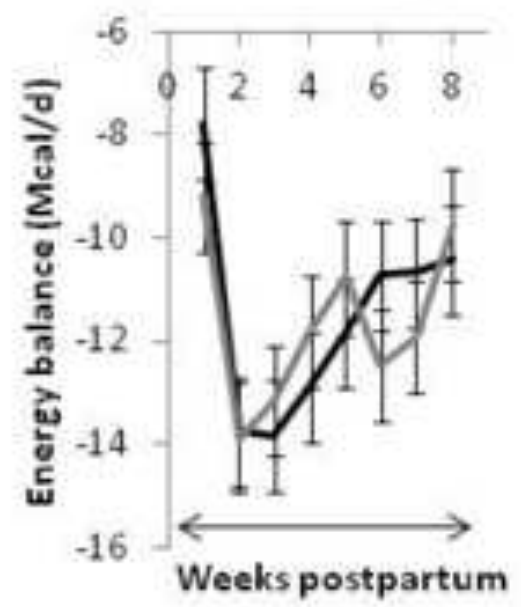



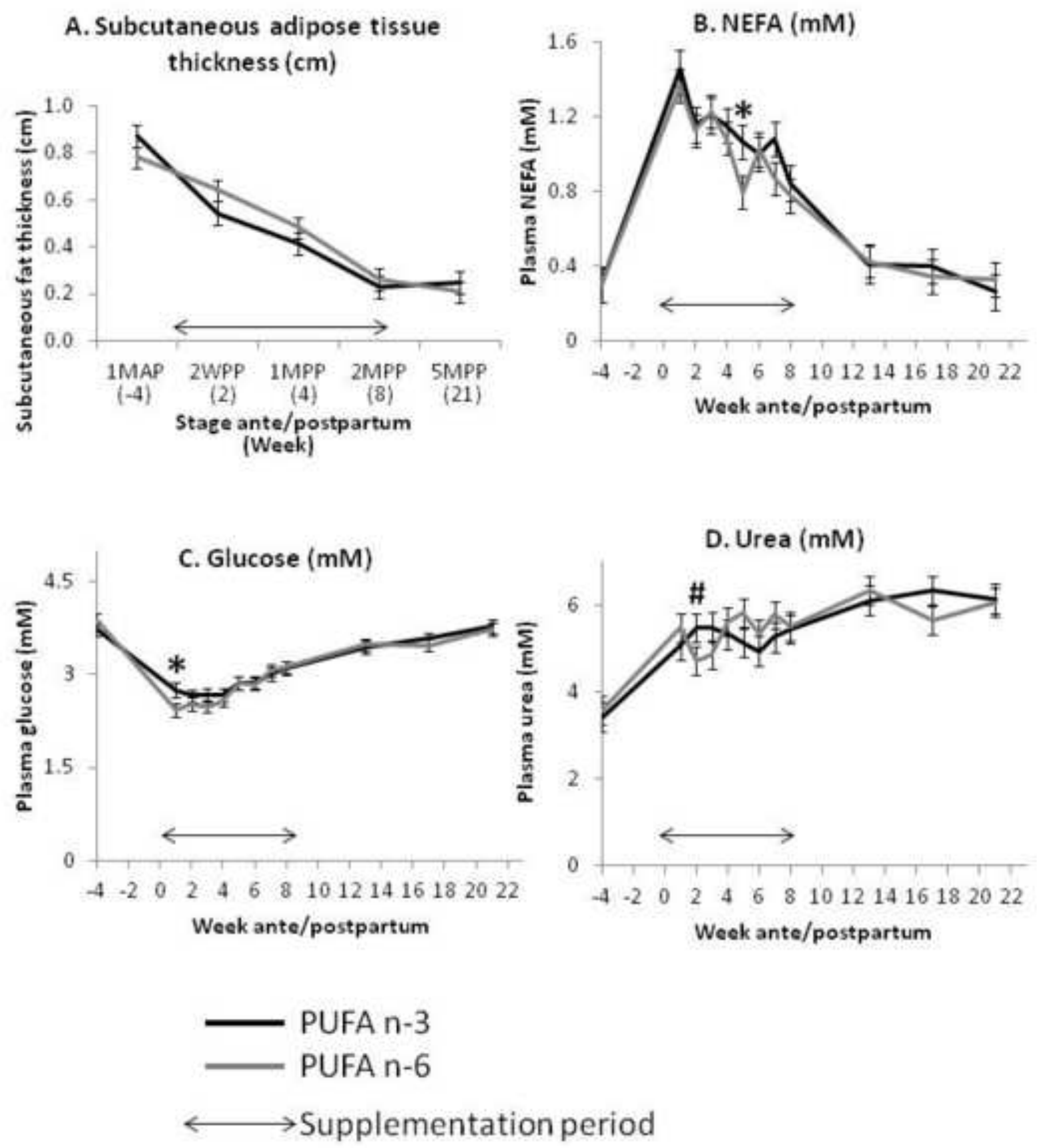

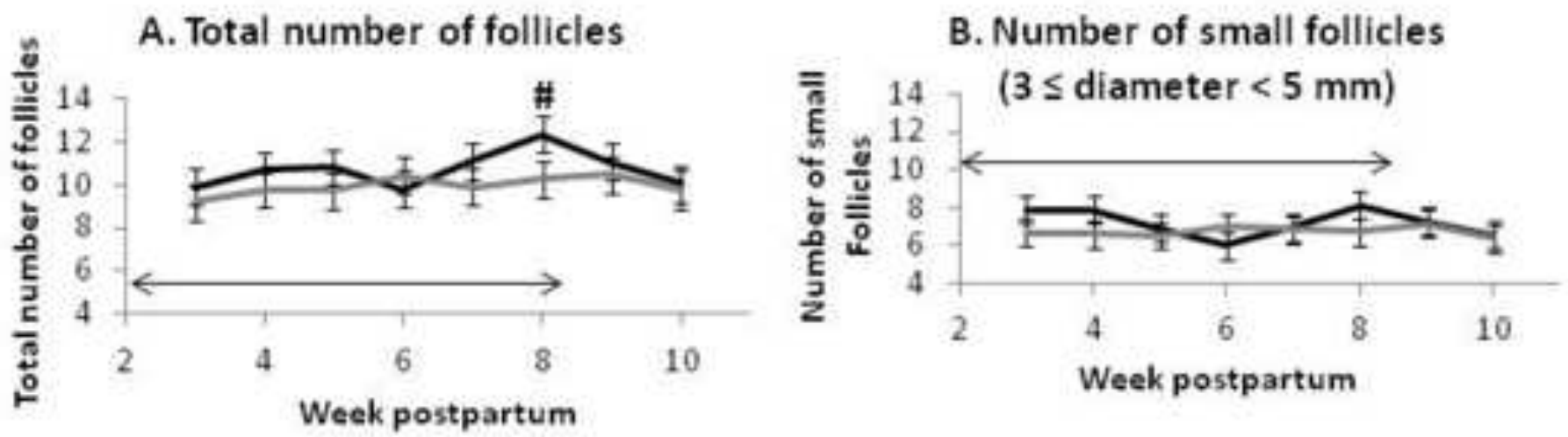

C. Number of medium follicles
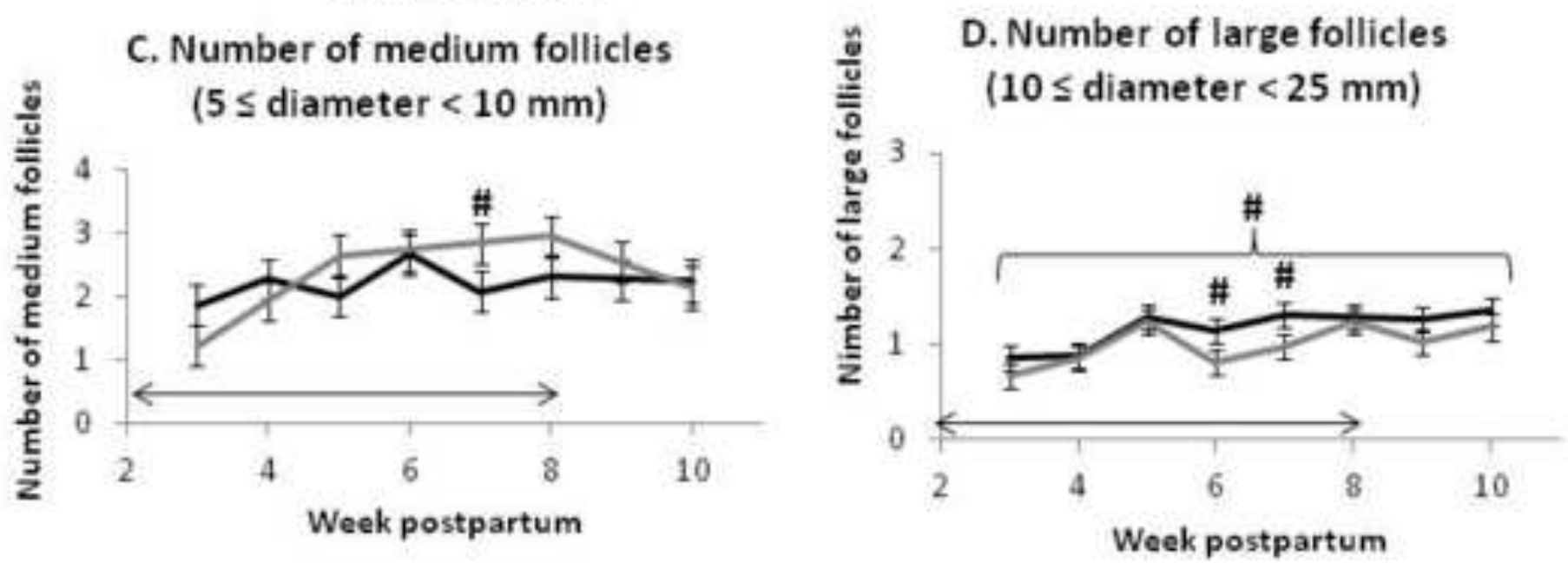

E. Number of large follicles

(10 $\leq$ diameter $<15 \mathrm{~mm}$ )
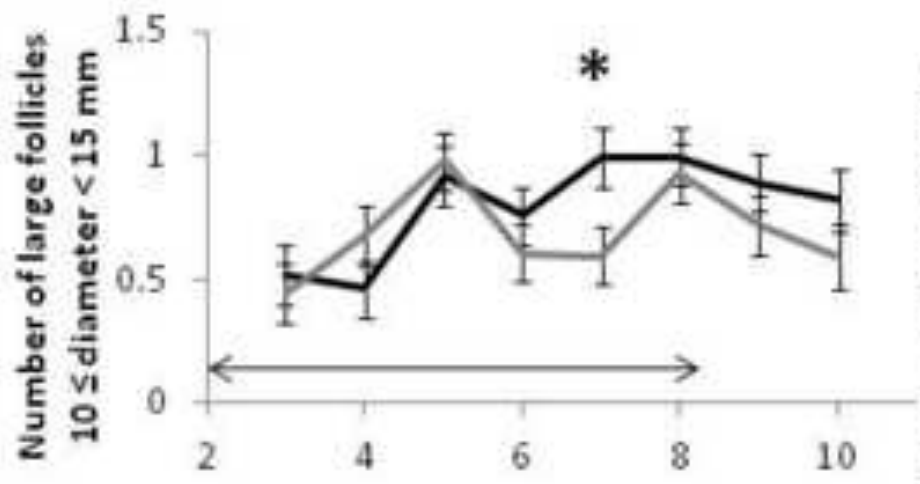

Week postpartum

F. Number of large follicles

(15 $\leq$ diameter $<25 \mathrm{~mm}$ )
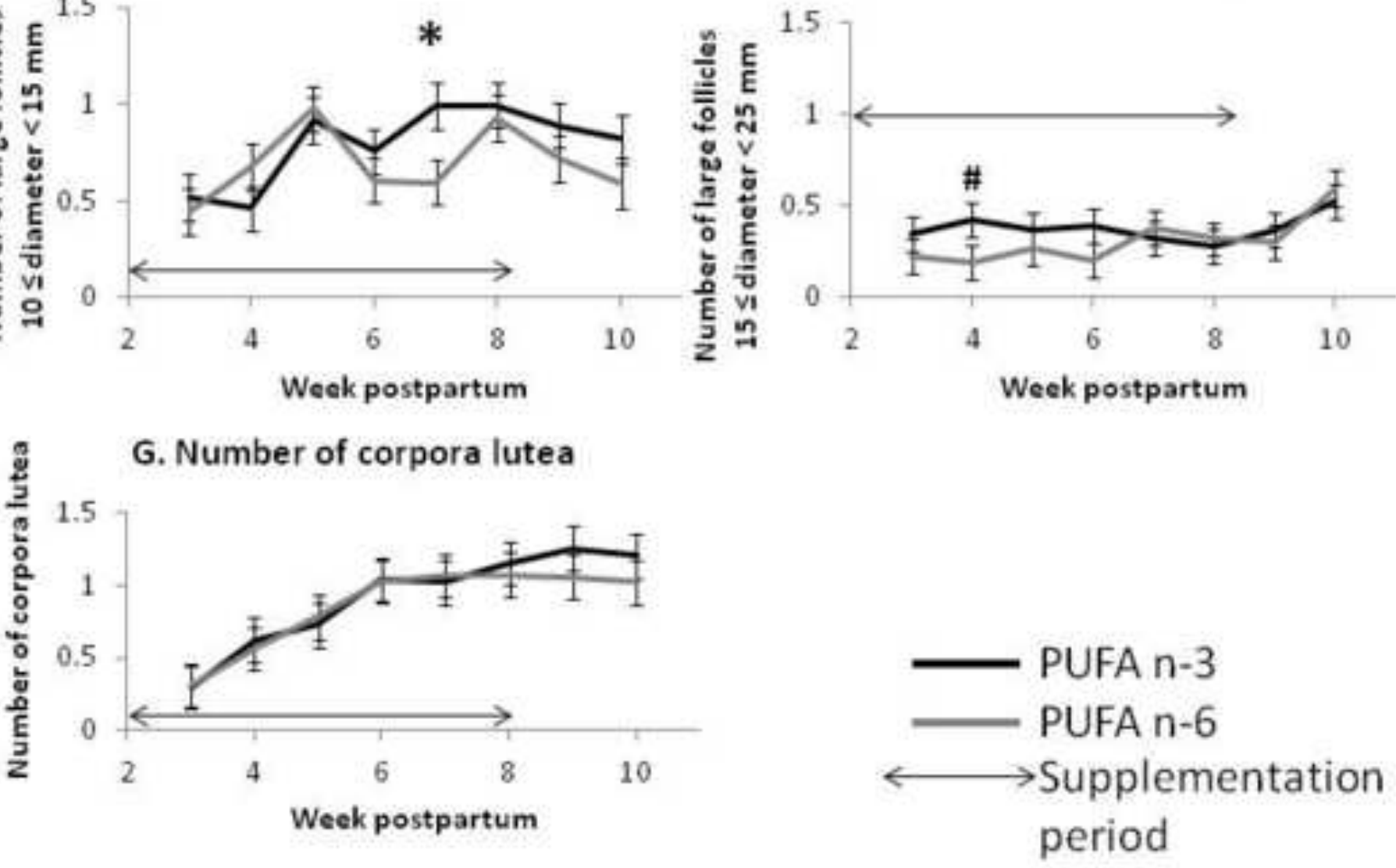